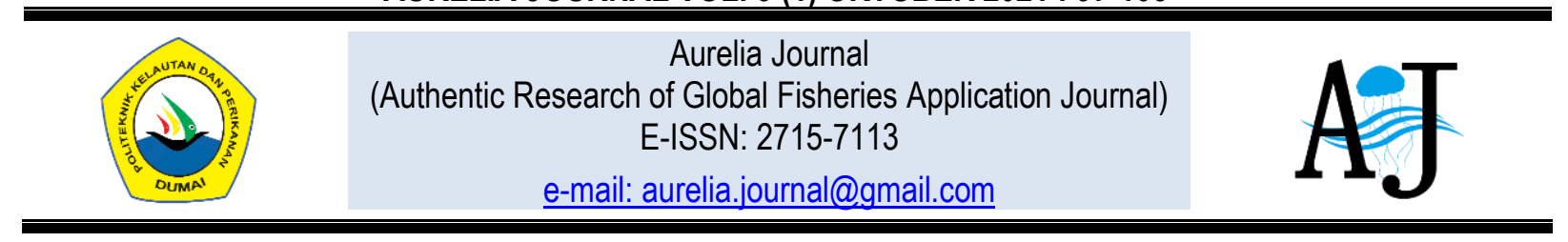

\title{
PENERAPAN TRACEABILITY PENGOLAHAN TUNA (Thunnus albacares) LOIN BEKU DI PT. BAHARI PRIMA MANUNGGAL JAKARTA BARAT
}

\section{(IMPLEMENTATION TRACEABILITY OF PROCESSING FROZEN TUNA (Thunnus albacares) LOIN AT PT. BAHARI PRIMA MANUNGGAL BARAT JAKARTA}

\author{
Nirmala Efri Hasibuan ${ }^{{ }^{*}}$, Kurnia Sada Harahap ${ }^{1}$, Neni Septia Emzuhri ${ }^{1}$ \\ ${ }_{1}^{1}$ Politeknik Kelautan dan Perikanan Dumai, Dumai, Riau, Indonesia \\ *Korespondensi: nirmala.efrihsb@gmail.com (N E Hasibuan) \\ Diterima 20 Agustus 2021 - Disetujui 20 September 2021
}

\begin{abstract}
ABSTRAK. Ikan tuna loin beku adalah salah satu produk unggulan ekspor dari PT. Bahari Prima Manunggal Jakarta Barat. Ikan tuna memiliki karakteristik pangan yang mudah rusak sehingga perlu dilakukan penelusuran untuk menjamin produk diterima dengan baik oleh konsumen. Traceability merupakan salah satu konsep mutu dan keamanan pangan yang disarankan untuk mendukung dan menjamin mutu produk. Sistem ketertelusuran (traceability) dibagi menjadi 2 bagian yaitu pengamatan ketertelusuran eksternal dan internal yang berfungsi sebagai alat dalam merekam jejak produksi dari suatu produk. Tujuan penelitian ini adalah mengetahui penerapan sistem traceability pada produk tuna loin beku secara eksternal dan internal di PT. Bahari Prima Manunggal Jakarta Barat. Metode penelitian yang dilakukan adalah metode deskriptif kualitatif dengan teknik pengumpulan data melalui partisipasi aktif, observasi, dan wawancara. Implementasi traceability di PT. Bahari Prima Manunggal Jakarta Barat menggunakan paper based system. Rekaman berupa form terdapat pada setiap tahapan proses mulai dari penerimaan bahan baku, penimbangan ikan utuh, catatan suhu harian, penimbangan loin, suhu chilling room, pemotongan loin, pemantauan pembekuan, penimbangan sebelum pengemasan, pengemasan dan pelabelan, pemeriksaan logam, suhu cold storage, loading dan stuffing. Sistem pengkodean digunakan sebagai alat pemantauan dan alat identifikasi disetiap proses produksi. Sistem pengkodean tuna loin beku terbagi dua yaitu kode alur proses dan kode produk akhir.
\end{abstract}

KATA KUNCI: Traceability, eksternal, internal, pembekuan, Thunnus albacares

ABSTRACT. Frozen loin tuna is one of the leading export products from PT. Bahari Prima Manunggal, West Jakarta. Tuna has food characteristics that are easily damaged so it is necessary to conduct a search to ensure the product is well received by consumers. Traceability is one of the concepts of quality and food safety that is recommended to support and guarantee product quality. The traceability system is divided into 2 parts, namely external and internal traceability observations which function as a tool in recording the production footprint of a product. The purpose of this study was to determine the application of the traceability system to frozen tuna loin products externally and internally at PT. Bahari Prima Manunggal, West Jakarta. The research method used is descriptive qualitative method with data collection techniques through active participation, observation, and interviews. Implementation of traceability at PT. Bahari Prima Manunggal West Jakarta uses a paper based system. Records of each stage of the process in the form of raw material receipts, whole fish weighing, daily temperature records, loin weighing, chilling room temperature, loin cutting, freezing monitoring, weighing before packaging, packaging and labeling, metal inspection, cold storage temperature and loading \& stuffing. The coding system is used as a monitoring and identification tool in every production process. The frozen tuna loin coding system is divided into two, namely the process flow code and the final product code.

KEY WORDS: Traceability, external, internal, freezing, Thunnus albacares

\section{Pendahuluan}

Ikan merupakan salah satu kelompok makanan yang kandungan proteinnya paling besar dikonsumsi masyarakat Indonesia. Indonesia adalah negara maritim yang memiliki potensi sumber daya laut yang luas dan hasil perikanan yang melimpah. Rata-rata konsumsi ikan di Indonesia tahun 2019 mencapai 
50,55 kkal per kapita/hari (Hakiki, 2020). Ikan tuna menjadi komoditas yang cukup digemari masyarakat. Indonesia sebagai negara yang memiliki hasil perikanan melimpah mengekspor hasil perikanan ke berbagai negara. Ekspor ikan segar/beku hasil tangkap pada tahun 2020-2021 terjadi kenaikan dari 35.896,2 menjadi 37.371,5 ton (BPS, 2021). Berdasarkan hal tersebut menunjukkan bahwa permintaan pasar ekspor terhadap produk perikanan terus mengalami peningkatan. Oleh sebab itu, keamanan dan pengawasan pangan menjadi perhatian besar konsumen. Adanya jaminan untuk keamanan produk pangan sangat penting sehingga dapat mencegah terjadinya kasus penolakan komoditas ekspor perikanan. Sistem ketertelusuran dianggap efektif alat untuk menjamin keamanan produk ikan dan meningkatkan transparansi rantai pasokan (Nicolae et al., 2017).

Sistem ketertelusuran (traceability) adalah sistem untuk menjamin kemampuan menelusuri riwayat, aplikasi atau lokasi dari suatu produk atau kegiatan untuk mendapatkan kembali data dan informasi melalui suatu identifikasi terhadap dokumen yang terkait (PP No 27. 2021.). Ketertelusuran dilakukan melalui dua sistem yaitu ketertelusuran internal dan ketertelusuran eksternal (KKP, 2021). Kualitas dan keamanan pangan penting bagi kesehatan manusia. Fokus penelitian saat ini adalah penggunaan ketertelusuran untuk memperoleh informasi tentang mutu dan keamanan pangan produk.

Beberapa penelitian terdahulu yang melakukan penelitian terkait penerapan traceability diantaranya Febrianik et al., (2017) melakukan pengamatan ketertelusuran pada pengolahan ikan lemadang yang menunjukkan masih adanya pemasok yang belum menerapkan system ketertelusuran. Menurut Putra \& Mangunsong, (2019) dalam penelitiannya menyatakan bahwa penggunaan system informasi seperti kode dapat membantu pengelolaan informasi sehingga memudahkan penelusuran produk tuna. Ketertelusuran yang baik dapat meminimalkan produksi dan distribusi produk yang tidak aman atau berkualitas buruk. Hal ini, meminimalkan gangguan perdagangan akibat masalah keamanan pangan dan potensi risiko kesehatan masyarakat (Kumperščak et al., 2019). PT. Bahari Prima Manunggal merupakan perusahaan ekspor swasta yang bergerak dibidang perikanan, khususnya untuk hasil perikanan dengan bahan baku ikan tuna. Penelitian ini bertujuan untuk mengkaji penerapan sistem ketertelusuran (traceability) pada pengolahan ikan tuna loin beku di PT. Bahari Prima Manunggal, serta kemampuan telusur pada produk akhir berdasarkan kode ketertelusuran.

\section{Metode Penelitian}

\subsection{Waktu dan Lokasi Penelitian}

Penelitian ini dilakukan di PT. Bahari Prima Manunggal di Jakarta Barat. Bahan yang digunakan dalam penelitian ini yaitu ikan tuna, air, es, alat tulis dan lembar wawancara. Alat yang digunakan adalah timbangan digital, pisau fillet, ABF (Air Blast Freezer), vacuum sealer.

\subsection{Metode}

Metode yang digunakan dalam penelitian ini adalah metode kualitatif deskriptif. Penelitian dilakukan dengan cara mengikuti langsung alur proses penanganan tuna loin beku di PT. Bahari Prima Manunggal mulai dari tahap penerimaan bahan baku hingga distribusi produk akhir. Data yang diperoleh terdiri atau data primer dan data sekunder. Inventarisasi data primer dilakukan secara langsung di lapangan melalui observasi, wawancara dan dokumentasi. Sedangkan data sekunder melalui studi pustaka, analisis dokumen, serta informasi dari instansi terkait.

Pengamatan ketertelusuran (traceability) dibagi menjadi 2 bagian yaitu pengamatan ketertelusuran internal dan eksternal. Ketertelusuran internal mencakup keseluruhan input dan proses dalam kegiatan pembekuan tuna loin. Sedangkan ketertelusuran eksternal mencakup praproduksi 
dengan identifikasi sumber bahan baku dan identifikasi distribusi pemasaran produk akhir. Kemampuan telusur ditentukan melalui sistem dokumentasi, perekaman dan sistem pengkodean dari setiap tahapan proses.

\section{Hasil dan Pembahasan}

\subsection{Penerapan Sistem Ketertelusuran Eksternal}

PT. Bahari Prima Manunggal melaksanakan ketertelusuran eksternal dengan system independent traceability yang biasa disebut dengan sistem tertutup, yang mana pemasok bertanggung jawab dalam memberikan informasi kepada pihak perusahaan atas produk yang dikirimkannya. Metode sistem ketertelusuran independen merupakan metode ketertelusuran eksternal yang dapat diterapkan oleh seluruh kapal pemasok ikan. Seluruh informasi dicatat dan direkam menggunakan paper based system (sistem berbasis kertas). Penerapan traceability secara manual memiliki kelemahan diantaranya membutuhkan biaya banyak untuk membeli perlengkapan alat tulis, memerlukan waktu banyak, membutuhkan tenaga kerja banyak dan mencurahkan tenaga untuk menulis kode berulang-ulang Masengi et al., (2018).

Ketertelusuran eksternal dibagi menjadi dua yaitu ketertelusuran terhadap sumber/asal bahan baku dimana UPI harus mampu mengidentifikasi asal bahan baku. Selanjutnya yang kedua ketertelusuran terhadap pemasaran/distribusi produk harus mampu mengidentifikasi kepada siapa produknya dikirim (KKP, 2021). Pertama, bahan baku yang digunakan di PT. Bahari Prima Manunggal adalah ikan tuna jenis Yellowfin, Bluefin, dan Big eye dalam keadaan segar dan beku. Lokasi penangkapan dilakukan berdasarkan Wilayah Pengelolaan Perikanan Negara Republik Indonesia (WPPNRI) 715 (KKP, 2014), dimana dalam hal ini daerah penangkapan ikan tuna berada di Daerah Bitung dan didaratkan di PT. Tirta Bitung Bahari. Bahan baku yang berasal dari daerah yang berbeda seperti Ambon dan Larantuka akan di berikan kode daerah yang berbeda. Proses penampungan ikan di supplier menggunakan mobil thermoking dengan suhu $0-1^{\circ} \mathrm{C}$.

PT. Bahari Prima Manunggal telah menerapkan sistem ketertelusuran dengan baik hingga ke daerah penangkapan bahan baku, ikan yang masuk ke perusahaan diberi kode yang menunjukkan nama daerah dan code supplier. Informasi awal yang diterima untuk bahan baku adalah nama pemasok bahan baku ikan, status CPIB, spesies ikan. alat tangkap dan lokasi penangkapan, jumlah tangkapan, total bahan baku yang diterima berdasarkan jenis dan size, kondisi suhu bahan baku. Hal tersebut telah sesuai dengan form ketertelusuran pemasok bahan baku pada peraturan BKIPM terkait penerapan sistem ketertelusuran di UPI (BKIPM, 2019). Penerapan sistem ketertelusuran pada perusahaan perikanan mengharuskan pihak pemasok atau nelayan memiliki data atau informasi penangkapan ikan yang jelas dan harus terdaftar memiliki surat ijin penangkapan ikan. Sistem ketertelusuran terhadap asal usul bahan baku membantu pencegahan penangkapan ikan secara illegal atau illegal, unreported and unregulated fishing (IUU). Penerapan sistem ketertelusuran tentunya sangat mendukung jaminan kualitas keamanan pangan (Hosch \& Blaha, 2017).

Kedua, penerapan sistem ketertelusuran terhadap pemasaran/distribusi produk untuk mengetahui jejak produk hingga sampai ke tangan pembeli. PT. Bahari Prima Manunggal sudah melakukan sistem ketertelusuran pada buyer dengan baik. Setiap proses ekspor dilakukan pencatatan pada form loading yang menunjukkan informasi tanggal pengiriman, jumlah produk yang dikirim, tujuan pengiriman, dan nomor invoice/surat jalan pengiriman. Komponen tersebut sesuai dengan form ketertelusuran eksternal untuk pelanggan dalam peraturan BKIPM terkait penerapan sistem 
ketertelusuran. Sistem tracking dipihak buyer bertujuan untuk mendapatkan data dan informasi terkait dengan pelanggan atau pengiriman suatu lot produk. Sistem ketertelusuran pemasaran telah dilakukan dengan baik dan mampu ditelusuri sehingga dapat mencegah hilangnya informasi pengiriman ke pihak buyer.

\subsection{Penerapan Sistem Ketertelusuran Internal}

Penerapan sistem ketertelusuran internal PT. Bahari Prima Manunggal dimulai dari penerimaan bahan baku sampai pada proses pemuatan. Tujuan dari penerapan sistem ketertelusuran ini adalah untuk mengenali dan menelusuri suatu produk pada setiap tahapan proses pengolahan maupun pemasaran. Rekaman form dari setiap tahapan proses pada bahan baku dilakukan pencatatan berupa kode. Sistem ketertelusuran di PT. Bahari Prima Manunggal dibuat oleh Quality Assurance (QA) dan diterapkan di Unit Pengolahan oleh Quality Control (QC) dan dilakukan pencatatan oleh tally. Masengi et al., (2018) dalam penelitiannya menyatakan bahwa kegiatan traceability juga dilaksanakan oleh QA dan QC yang selanjutnya dipertanggung jawabkan oleh kepala produksi. Identifikasi perekaman pada alur proses pengolahan tuna loin beku di PT. Bahari Prima Manunggal dapat dilihat pada Tabel 1.

Tabel 1. Identifikasi Rekaman Alur Proses Pengolahan Tuna Loin Beku.

\begin{tabular}{ll}
\multicolumn{1}{c}{ Tahapan Proses } & \multicolumn{1}{c}{ Rekaman } \\
\hline Penerimaan bahan baku & Form harian penerimaan bahan baku \\
Penimbangan I & Form hasil uji organoleptik, kimia dan mikrobiologi \\
Pencucian & Form laporan penimbangan ikan utuh \\
Pemotongan kepala & Form catatan suhu harian \\
Pembentukan loin & Form catatan suhu harian \\
Pembuangan tulang, daging hitam, kulit & Form catatan suhu harian \\
Perapihan & Form catatan suhu harian \\
Penimbangan II & Form catatan suhu harian \\
Pemberian gas CO & Form laporan penimbangan loin \\
Pendinginan (chilling room) & - \\
Pemeriksaan akhir dan penentuan ukuran & Form laporan suhu chilling room \\
Vacuum & Form laporan harian pemotongan loin \\
Pelipatan & Form catatan suhu harian \\
Pembekuan & Form catatan suhu harian \\
Penimbangan III & Form laporan pemantauan pembekuan \\
Pengemasan dan pelabelan & Form laporan penimbangan sebelum pengemasan \\
Pemeriksaan logam & Laporan Harian pengemasan dan pelabelan \\
Penyimpanan (cold storage) & Form harian pemeriksaan logam \\
Pengangkutan (Stuffing) & Form laporan suhu cold storage \\
\hline
\end{tabular}

Penanganan pada proses penerimaan bahan baku harus dilakukan dengan cepat dan hati hati sesuai dengan ketentuan SNI 014104.3-2006 meliputi: bahan baku yang diterima di unit pengolahan diuji secara organoleptik, untuk mengetahui mutunya (BSN, 2006). Pada tahap penerimaan bahan baku didapatkan rekaman yang berisi informasi mengenai tanggal penerimaan, kode supplier, grade, temperatur, nomor batch, uji organoleptik (bau, tekstur dan warna) yang dicatat dalam laporan harian penerimaan bahan baku. Selain uji sensori terdapat pengujian mikrobiologi yaitu uji e-coli, salmonella dan coliform serta pengujian secara kimia yaitu kadar histamin. Bahan baku akan diterima apabila 
memenuhi standar yang ditetapkan oleh perusahaan. Pada tahap penerimaan bahan baku diberikan kode internal kedatangan yang berisi asal daerah tangkapan dan tanggal penerimaan bahan baku.

Tahapan selanjutnya adalah penimbangan yang bertujuan untuk menentukan rendemen yang akan diperoleh dan untuk menyesuaikan apakah bobot ikan yang diterima sesuai atau tidak ketika ikan tuna tersebut diperoleh dari transit. Sebelum melakukan penimbangan, timbangan harus dikalibrasi terlebih dahulu, kalibrasi timbangan dilakukan oleh QC. Selanjutnya pada tahapan pencucian, ikan yang telah dibersihkan dari insang dan perut dicelupkan ke dalam air dingin dengan konsentrasi klorin 200 ppm sampai semua bagian tubuh terendam selama 5-10 detik. Pemberian klorin dapat mengurangi jumlah dan jenis bakteri psikrofil. Pencucian ikan tuna tersebut bertujuan untuk menghilangkan dan membersihkan kotoran, darah, lendir, dan benda asing yang menempel pada ikan tuna sehingga dapat mengurangi jumlah mikrobia (Nento, 2015).

Kemudian tahapan pemotongan kepala, pembentukan loin, pembuangan tulang, daging hitam kulit perapihan, penimbangan dan pemberian gas $\mathrm{CO}$ dilakukan secara cepat dan hati-hati serta suhu dipertahankan $17-21^{\circ} \mathrm{C}$. Ikan yang telah dikemas dan ditambahkan dengan gas CO kemudian disimpan dalam chilling room untuk menjaga temperature sesuai standard $\left(0,1-3,3^{\circ} \mathrm{C}\right)$ selama $36-48$ jam / sekitar 2 hari. Pengontrolan suhu chilling room dilakukan setiap jam dan direkam dalam form pencatatan suhu sehingga suhu dapat dikontrol dengan tepat. Loin yang disimpan dalam ruangan chilling selama 1-2 hari dikeluarkan dari ruang pendingin dan dilakukan pemeriksaan tahap akhir. Penentuan ukuran dilakukan untuk penyeragaman ukuran dan bobot loin sesuai dengan permintaan konsumen. Tahap ini dilakukan dengan cara memotong loin dari bagian kepala ke ekor dengan panjang 20-30 cm kemudian ditimbang dengan berat 1,36-3,13 kg (size 3/6) dan 2,27-4,04 kg (size 5/8). Data di catat dalam form laporan harian pemotongan loin. Kemudian dilanjutkan proses vakum dan pelipatan dengan memperhatikan suhu $17-21^{\circ} \mathrm{C}$.

Proses berikutnya adalah pembekuan dengan menggunakan Air Blast Freezer (ABF) dengan suhu $A B F$ mencapai $-40^{\circ} \mathrm{C}$ selama 6 jam. Dalam ruangan air blast freezer (ABF) terdapat dua buah kipas (blower) yang berfungsi untuk menghembuskan udara dingin pada produk dan empat buah rak untuk meletakkan 160 long pan berbahan stainless steel (Dewayani, 2016). Produk yang telah beku dikeluarkan dari keranjang plastik untuk diperiksa satu per satu kemudian ditimbang. Tuna loin beku selanjutnya dilakukan pengemasan untuk mencegah terjadinya kontaminasi silang dengan lingkungan. Sebelum pengemasan dalam master carton tuna loin beku dilakukan pembublean selanjutnya dikemas 4-5 loin ke dalam Master Carton (MC) yang telah diberi label yang bertuliskan nama produk, nama perusahaan, spesifikasi produk, negara asal, ukuran, berat bersih, dan kode produksi. Ketertelusuran internal bahan kemasan yang digunakan juga perlu diketahui. Pengemasan dilakukan sesuai dengan size dan grade loin. Pelabelan bertujuan untuk memudahkan konsumen dalam mengenali produk karena berisi informasi-informasi mengenai produk itu sendiri (Sofiati \& Deto, 2019).

Informasi ketertelusuran internal bahan kemasan di PT. Bahari Prima Manunggal terdiri dari nama, ukuran dan jenis kemasan, tanggal kedatangan, nama produsen/pemasok kemasan serta jumlah bahan yang diterima. Kemasan yang diidentifikasi oleh QC mencakup kemasan primer, sekunder dan tersier. Tracing terhadap bahan kemasan dilakukan untuk memastikan bahan material kemasan aman dan dapat dipantau apabila terdapat kekeliruan tehadap bahan kemasan. Ketertelusuran asal usul bahan kemasan paling sedikit mencakup nama bahan, nama dan alamat pemasok, deskripsi material untuk bahan kemasan, tanggal pengiriman dan kedatangan, dan jumlah penerimaan (BKIPM, 2019). 
Selanjutnya tahap pemeriksaan logam dilakukan untuk mencegah terjadinya kontaminasi dari serpihan logam. Rekaman berupa laporan monitoring metal detector. Pengecekan melalui metal detector berperan untuk untuk mengetahui masuknya benda atau barang yang tidak sesuai dengan deskripsi produk (Sofiati \& Deto, 2019). Produk tuna beku yang telah dikemas disimpan dalam ruang penyimpanan beku (cold storage) dengan suhu $\leq-20^{\circ} \mathrm{C}$. Produk dalam cold storage disimpan hingga dilakukan pemindahan atau pengangkutan (stuffing) untuk diekspor. Kontrol suhu cold storage dilakukan setiap jam oleh Selama proses penyimpanan dan pengangkutan dilakukan pencatatan suhu yaitu sekitar $-20^{\circ} \mathrm{C}$ dipantau setiap jam oleh staf $\mathrm{QC}$ dan jumlah produk dalam form laporan harian suhu.

Pada ketertelusuran internal selain diperoleh rekaman setiap tahapan proses juga ditemukan rekaman pembersihan dan sanitasi serta rekaman verifikasi. Rekaman pembersihan dan sanitasi mencakup keterangan jadwal pembersihan dan sanitasi, bahan dan alat sanitasi yang digunakan serta petugas sanitasi. Rekaman verifikasi paling sedikit memuat hasil pengujian untuk bahaya mikrobiologi, fisik, dan kimia serta kalibrasi peralatan (KKP. 2021). PT. Bahari Prima Manunggal telah menerapkan ketertelusuran pada kegiatan pembersihan dan sanitasi dengan adanya laporan hasil sanitasi harian, ceklis sanitasi area dan sarana mingguan kemudian diikuti dengan hasil swab area secara mikrobiologi. Selanjutnya untuk rekaman verifikasi PT. Bahari Prima Manunggal berupa laporan hasil uji mikrobiologi, kimia, sensori, kemudian dilengkapi dengan sertifikat HACCP, SKP dan hasil kalibrasi alat yang bekerjasama dengan pihak laboratorium kalibrasi.

\subsection{Sistem Pengkodean}

Pengkodean dapat berupa kode numerik sederhana atau kompleks dan diletakkan pada kemasan produk akhir dengan tujuan mempermudah penelusuran secara menyeluruh, baik penelusuran ke belakang (tracing) maupun penelusuran ke depan (tracking). Dalam era perdagangan global, penerapan barcode atas produk-produk dan jasa-jasa menjadi mutlak demi efisiensi dan kemudahan pengelolaan rantai suplai mulai dari pabrik, gudang, distributor hingga pengecer. Penerapan barcode adalah syarat mutlak bagi keterlibatan usaha anda dalam perdagangan modern. Sistem aplikasi identifikasi GS1 dapat menyatakan basis data dalam bentuk kode numerik. Kode dapat berupa kode batang, RFID atau system lainnya (Goulding, I.C, 2016).

Sistem pengkodean di PT. Bahari Prima Manunggal terbagi menjadi dua yaitu kode alur proses untuk proses produksi dan menggunakan sistem barcode untuk produk jadi (kode lot produk). PT. Bahari Prima Manunggal menggunakan barcode 1D pada kode produk akhir. Pertama, kode alur proses pembekuan tuna loin beku di PT. Bahari Prima Manunggal menggunakan kode yang terdiri dari 10digit angka. Berdasarkan Gambar 1 kode alur produksi terdiri dari dua digit pertama (23) dari kode daerah, dua digit kedua (29) dari tanggal penerimaan bahan baku, dua digit ketiga (05) dari bulan penerimaan bahan baku, dua digit keempat (21) dari tahun penerimaan bahan baku, dan dua digit kelima (30) dari tanggal produksi.

\section{0}

(Sumber: Dokumentasi PT. Bahari Prima Manunggal, 2021)

Gambar 1. Contoh kode alur proses tuna loin beku di PT. Bahari Prima Manunggal. 
Kedua, kode lot produk tuna loin beku di PT. Bahari Prima Manunggal menggunakan terdiri dari 12digit angka. Berdasarkan Gambar 2, terdapat 12digit angka yang meliputi angka 0 merupakan karakter sistem bilangan, angka 40232 merupakan ID perusahaan dan angka 14506 merupakan urutan registrasi produk, dan angka 3 merupakan jenis produk.

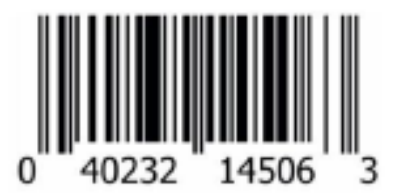

(Sumber: Dokumentasi PT. Bahari Prima Manunggal, 2021)

\section{Gambar 2. Contoh kode lot produk tuna loin beku di PT. Bahari Prima Manunggal.}

\subsection{Kemampuan Telusur}

Setiap unit pengolahan harus mampu menerapkan sistem ketertelusuran yang mampu mengidentifikasi lot produk dan keterkaitannya dengan batch bahan baku, rekaman proses dan pengiriman. Sistem ketertelusuran harus mampu mengidentifikasi bahan yang masuk dari pemasok langsung dan rantai awal distribusi produk akhir (SNI, 2009). Kemampuan telusur produk tuna loin beku di PT. Bahari Prima Manunggal berdasarkan alur proses terdapat pada Tabel 2. Berdasarkan Tabel 2 dapat diketahui bahwa setiap tahapan proses pada pembekuan tuna loin beku di PT. Bahari Prima Manunggal mampu ditelusuri.

Tabel 2. Kemampuan telusur produk tuna loin beku di PT. Bahari Prima Manunggal.

\begin{tabular}{|c|c|c|c|}
\hline \multirow[b]{2}{*}{ Tahapan Proses } & \multirow[b]{2}{*}{ Kode Produk } & \multicolumn{2}{|c|}{ Kemampuan Telusur } \\
\hline & & $\begin{array}{l}\text { Mampu } \\
\text { Telusur }\end{array}$ & $\begin{array}{c}\text { Tidak Mampu } \\
\text { Telusur }\end{array}$ \\
\hline Penerimaan bahan baku & $\begin{array}{c}\text { Bitung } \\
29 / 05 / 21\end{array}$ & $\sqrt{ }$ & \\
\hline Penimbangan I & 2329052130 & $\sqrt{ }$ & \\
\hline Pencucian & 2329052130 & $\sqrt{ }$ & \\
\hline Pemotongan kepala & 2329052130 & $\sqrt{ }$ & \\
\hline Pembentukan loin & 2329052130 & $\sqrt{ }$ & \\
\hline Pembuangan tulang, daging hitam, kulit & 2329052130 & $\sqrt{ }$ & \\
\hline Perapihan & 2329052130 & $\sqrt{ }$ & \\
\hline Penimbangan II & 2329052130 & $\sqrt{ }$ & \\
\hline Pemberian gas $\mathrm{CO}$ & 2329052130 & $\sqrt{ }$ & \\
\hline Pendinginan (chilling room) & 2329052130 & $\sqrt{ }$ & \\
\hline Pemeriksaan akhir dan penentuan ukuran & 2329052130 & $\sqrt{ }$ & \\
\hline Vacuum & 2329052130 & $\sqrt{ }$ & \\
\hline Pelipatan & 2329052130 & $\sqrt{ }$ & \\
\hline Pembekuan & 2329052130 & $\sqrt{ }$ & \\
\hline Penimbangan III & 2329052130 & $\sqrt{ }$ & \\
\hline Pengemasan dan pelabelan & 2329052130 & $\sqrt{ }$ & \\
\hline Pemeriksaan logam & 2329052130 & $\sqrt{ }$ & \\
\hline Penyimpanan (cold storage) & 2329052130 & $\sqrt{ }$ & \\
\hline Pengangkutan (Stuffing) & 2329052130 & $\sqrt{ }$ & \\
\hline
\end{tabular}




\section{Kesimpulan}

Penerapan sistem ketertelusuran internal dan eksternal oleh UPI menggunakan sistem paper based. Penerapan sistem ketertelusuran eksternal pada pihak supplier dan pihak buyer sudah dilakukan berupa pencatatan dan pengkodean. Pengkodean yang diterapkan untuk supplier unit pengolahan mampu mengidentifikasi supplier/daerah, tanggal penerimaan dan tanggal produksi. Penerapan sistem ketertelusuran pada pihak buyer berdasarkan pencatatan pada form loading yang mencantumkan tanggal pengiriman, jumlah produk yang dikirim, tujuan pengiriman, dan surat jalan pengiriman. Pengkodean pada sistem ketertelusuran internal dimulai dari tahap penerimaan bahan baku hingga tahap stuffing. Sistem pengkodean di PT. Bahari Prima Manunggal terbagi menjadi dua yaitu kode alur proses untuk proses produksi dan menggunakan sistem barcode untuk produk jadi (kode lot produk). Kode tuna loin beku di PT. Bahari Prima Manunggal pada alur proses produksi menggunakan 10digit angka, sedangkan kode lot produk menggunakan barcode 1D yang terdiri dari 12digit angka.

\section{Daftar Pustaka}

[BSN] Badan Standarisasi Nasional (2006). SNI 01-4104.2-2006. Tuna loin beku-Bagian 2: Persyaratan bahan baku

[BSN] Badan Standarisasi Nasional.(2009). SNI ISO 22000:2009. Sistem Manajemen Keamanan Pangan-Persyaratan untuk Organisasi dalam Rantai Pangan.

BPS. (2021). Buletin Statistik Perdagangan Luar Negeri Ekspor Menurut Kelompok Komoditi dan Negara, Agustus 2021. Badan Pusat Statistik

BKIPM. (2019). Peraturan Kepala Badan Karantina Ikan Pengendalian Mutu, dan Keamanan Hasil Perikanan Nomor 170/PER-BKIPM/2019 Tentang Penerapan Sistem Ketertelusuran di Unit Pengolahan Ikan.

Dewayani, G M, 2016. (2016). Penerapan Metode Air Blast Freezing (Abf) Pada Pembekuan Ikan Salmon Chum (Oncorhynchus Keta) Di Pt. Marine Cipta Agung, Pasuruan, Jawa Timur. 1-72.

Febrianik, D., Dharmayanti, N., \& Siregar, A. N. (2017). Penerapan Sistem Ketertelusuran Pada Pengolahan Ikan Lemadang Portion Beku Di Pt. Graha Insan Sejahtera , Jakarta Utara. Jurnal Pengolahan Hasil Perikanan Indonesia, 20(1), 179-187.

Goulding, I.C. (2016). Manual on Traceability Systems for Fish and Fishery Products for Cooperation on Agriculture (IICA) (Issue 13).

Hakiki, G. (2020). Konsumsi Kalori dan Protein Penduduk Indonesia dan Provinsi, Maret 2020. Badan Pusat Statistika

[KKP] Kementerian Kelautan dan Perikanan (2014). Peraturan Menteri Kelautan dan Perikanan Republik Indonesia No.18/PERMEN-KP/2014 Tentang Wilayah Pengelolaan Perikanan Negara Republik Indonesia.

[KKP] Kementerian Kelautan dan Perikanan (2021). Peraturan Menteri Kelautan dan Perikanan Republik Indonesia Nomor 29 Tahun 2021 Tentang Sistem Ketertelusuran dan Logistik Ikan Nasional.

Kumperščak, S., Medved, M., Terglav, M., Wrzalik, A., \& Obrecht, M. (2019). Traceability Systems and Technologies for Better Food Supply Chain Management. Quality Production Improvement - QPI, 1(1), 567-574. https://doi.org/10.2478/cqpi-2019-0076

Masengi, S., Sipahutar, Y. H., \& Sitorus, A. C. (2018). Penerapan Sistem Ketertelusuran (Traceability) Pada Produk Udang Vannamei Breaded Beku (Frozen Breaded Shrimp) Di Pt. Red Ribbon

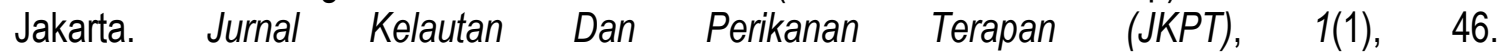
https://doi.org/10.15578/jkpt.v1i1.7252

Nento R W, 2015. (2015). Studi Pengemasan Tuna Ekor Kuning ( Thunnus Albacares ) Kelurahan Bone Pantai Provinsi Gorontalo. 1, 55-59.

Nicolae, C. G., Moga, L. M., Bahaciu, G. V., \& Marin, M. P. (2017). Traceability System Structure 
Design for Fish and Fish Products Based on Supply Chain Actors Needs. Scientific Papers-Series D-Animal Science, 60(September), 353-358.

PP No 27. (2021). Peraturan Pemerintah Republik Indonesia Nomor 27 Tahun 2021 Tentang Penyelenggaraan Bidang Kelautan dan Perikanan.

Putra, I. G. S. E., \& Mangunsong, S. (2019). Sistem Informasi Pengolahan Ikan Tuna Untuk Ketertelusuran Perikanan Skala Kecil. Jurnal IPTEKS Pemanfaatan Sumberdaya Perikanan, 6(11), 90-101. https://doi.org/10.20956/jipsp.v6i11.6379

Sofiati, T., \& Deto, Siti Nurbaya, 2019. (2019). Profil Pengolahan Tuna Loin Beku di PT . Harta Samudra Kabupaten Pulau Morotai. Jurnal Bluefien Fisheries, 1(2), 12. 
